\title{
Quality of life evaluation of coinfected patients with HIV/tuberculosis in a hospital in Northeast Brazil
}

\author{
Amanda Danielle SILVA ${ }^{1}$ (D) , Thaylany Crysley AMORIM ${ }^{1}$ (D) , Ádeny Marccy ARAGÃO ${ }^{1}$ (D), \\ Maria José IBAÑEZ ${ }^{2}$ (D) , José de Arimatea FILHO² (D), Rosali Maria SILVA ${ }^{1}$ (D) \\ ${ }^{1}$ Universidade Federal de Pernambuco \\ ${ }^{2}$ Hospital das Clínicas da Universidade Federal de Pernambuco \\ Corresponding author: Silva AD, amandadanielles@gmail.com
}

Submitted: 31-10-2018 Resubmitted: 01-05-2020 Accepted: 02-05-2020

Peer review: blind reviewer and Priscila Rosalba Oliveira

\begin{abstract}
Objectives: To evaluate the quality of life of patients coinfected with HIV/tuberculosis and to understand their perception of their health. Methods: A cross-sectional study was carried out in a hospital in the state of Pernambuco, Brazil. Data were collected between November 2017 and April 2018 through interviews. The WHOQOL-HIV Bref instrument was used, obtaining the total score and performance in the domains: physical, psychological, level of independence, social relationships, environment, spirituality. Sociodemographic and clinical data from the Logistic Control System of Medicines $\left(S_{\text {SICLOM }}{ }^{\circledR}\right)$ were also collected through a questionnaire. Results: Twenty-six patients were interviewed, $76.9 \%$ were male, mostly heterosexual, single, $43.1 \%$ presented an advanced state of immune system compromise. $73.1 \%$ considered their health "good" or "very good" and 69.2\% did not consider themselves sick. The general quality of life, score from zero (worst quality of life) to one hundred (best quality of life) obtained an average of $69.6 \pm 9.1$. In the domains, the worst average was obtained at the independence level $(11.1 \pm 2.6)$ and the highest scores were in the spirituality (15.5 \pm 3.8$)$ and psychological $(15.3$ \pm 2.2 ) domains. Conclusions: The low level of independence and the unfavorable socioeconomic conditions were important aspects influencing in the quality of life of the studied population. Knowledge about the most affected domains in the quality of life allows the elaboration of clinical guidelines and public assistance policies that contribute to the well-being of these patients.
\end{abstract}

Keywords: quality of life, acquired immunodeficiency syndrome, tuberculosis, coinfection, social stigma.

\section{Avaliação da qualidade de vida de pacientes coinfectados com HIV/tuberculose em um hospital do Nordeste do Brasil}

\section{Resumo}

Objetivos: Avaliar a qualidade de vida de pacientes coinfectados com HIV/tuberculose em tratamento, identificando as alterações na qualidade de vida e conhecendo a percepção dos mesmos sobre a sua saúde. Métodos: Realizou-se um estudo transversal em um hospital no estado de Pernambuco, Brasil. Os dados foram coletados entre novembro de 2017 e abril de 2018 , por meio de entrevistas. Foi utilizado o instrumento WHOQOL-HIV Bref, obtendo-se a pontuação total e o desempenho nos domínios físico, psicológico, nível de independência, relações sociais, meio ambiente e espiritualidade. Também foi utilizado um questionário para coleta de dados sociodemográficos e clínicos a partir do registro de dispensação da farmácia e dados do Sistema de Controle Logístico de Medicamentos (SICLOM ${ }^{\circledR}$ ). Resultados: Foram entrevistados 26 pacientes, dentre os quais 76,9\% eram do gênero masculino, em sua maioria heterossexuais, solteiros, em idade produtiva (29-38 anos), sem vínculo empregatício e com condições socioeconômicas desfavoráveis. Dentre os entrevistados, 46,1\% apresentavam avançado estado de comprometimento imunológico. 73,1\% considerou sua saúde "boa" ou "muito boa" e 69,2\% não se consideravam doentes. A qualidade de vida geral, score de zero (pior qualidade de vida) a cem (melhor qualidade de vida) teve como média 69,6 $\pm 9,1$. Quanto aos domínios, a pior média foi obtida no nível de independência $(11,1 \pm 2,6)$ e as maiores pontuações foram dos domínios espiritualidade $(15,5 \pm 3,8)$ e psicológico $(15,3 \pm 2,2)$. Conclusões: 0 baixo nível de independência e as condições socioeconômicas desfavoráveis foram importantes aspectos influenciadores na qualidade de vida da população estudada. O conhecimento dos aspectos mais prejudicados na qualidade de vida permite a elaboração de diretrizes clínicas e políticas públicas assistenciais que contribuam com o bem-estar desses pacientes.

Palavras-chave: qualidade de vida, síndrome de imunodeficiência adquirida, tuberculose, coinfecção, estigma social. 


\section{Introduction}

Tuberculosis (TB) remains one of the most incident opportunistic infections and the leading cause of death among people living with HIV/AIDS (PLWHA). In 2018, the chances of becoming ill with TB were 19 times higher for PLWHA than for those without HIV ${ }^{1}$.

Both AIDS and TB are stigmatized diseases. Cases of HIV/TB co-infection are even more complex, since the synergistic relationship between these diseases increases the resulting complication rate ${ }^{2}$.

Brazil is among the 20 countries with the highest estimated number of TB cases among people living with $\mathrm{HIV}^{3}$. In addition, a number of studies in several countries show that simultaneous infection by HIV and by Mycobacterium tuberculosis significantly affects the quality of life of the patients ${ }^{4,5,6}$.

Quality of life has a broad concept and can be related to different aspects of the individual's life: social, physical, and psychic ${ }^{7}$. In this context, the assessment of quality of life plays a very important role when it comes to living with diseases characterized by dense aspects of stigma, fear, expectation of death, and suffering, as in the case of the combination of AIDS and TB'

Several studies address the theme of HIV/TB co-infection; however, few focus on the quality of life of this population. Therefore, it is of great importance to carry out studies in local populations, both to establish practical interventions in the physical and psychosocial environments of these patients, as well as to create public health policies aimed at improving their quality of life ${ }^{6}$.

Therefore, this study aimed to assess the quality of life of HIV/TB co-infected patients undergoing treatment, identifying changes in quality of life and knowing their perception of their health.

\section{Methods}

A cross-sectional study with a quantitative approach was carried out. Data collection took place in a hospital located in the city of Recife-PE, in the Pharmacy sector, classified as an HIV/AIDS specialist care service.

A non-probabilistic sample was used for convenience. The studied population consisted of all the HIV/TB coinfected patients, registered in the Logistics Control System for Medications (Sistema de Controle Logístico de Medicamentos, SICLOM ${ }^{\circ}$ ), who attended the hospital's outpatient pharmacy to receive antiretroviral drugs from November 2017 to April 2018.

In total, 26 patients were interviewed, who met the following inclusion criteria: patients of both genders, with a confirmed diagnosis of HIV and TB infection, aged 18 years old or older, registered in the $\mathrm{SICLOM}^{\circ}$, who attended outpatient visits during the data collection period, and who agreed to participate in the study.

Patients under the age of 18 , patients with significant cognitive deficits that may interfere with the questionnaire responses, and those who did not accept to participate in the research or did not sign the Free and Informed Consent Form (FICF) were excluded.

The WHOQOL-HIV Bref questionnaire, validated in Brazil $^{6}$ was used to assess the patients' quality of life. It contains 31 items, which are evaluated based on the Likert scale, where the score ranges from 1 to 5. The items are divided into 6 domains: physical, psychological, level of independence, social relations, environment, and spirituality.

In addition, another questionnaire was applied to collect sociodemographic and clinical data from the pharmacy dispensation registry and from the Logistics Control System for medications (SICLOM ${ }^{\circ}$ ).

The sociodemographic variables evaluated were the following: age, gender, marital status, education level, family income, professional activity, city, and state. The following clinical variables were also evaluated: TCD4+ lymphocyte count, viral load, anti-retroviral therapy, tuberculostatic therapy, month of TB treatment in which the patient is, and comorbidities.

Regarding the calculation of the score obtained in WHOQOLHIV Bref, the minimum expected score was 31 (equivalent to the minimum score in all responses) and the maximum was 155 (equivalent to the maximum score in all responses), calculated by the sum of each response given by the patients individually. This score was converted into a scale from 0 to 100 for a better understanding of the values.

Regarding the calculation of the score for each domain, which varies between 4 and 20, the equations provided in the "Scoring and Coding for the WHOQOL-HIV Instruments"9 WHOQOL-HIV user manual were used. These data were described using means and standard deviations.

The reliability of the instrument was assessed by analyzing the consistency of the items with the calculation of the Cronbach's Alpha coefficient, where values greater than or equal to 0.7 are considered acceptable.

All the collected data were stored in Excel $^{\circ}$ spreadsheets and the other results were represented by means of a percentage calculation.

In order to identify which factors interfered in the interviewees' quality of life, the scores in the WHOQOL-HIV Bref domains were evaluated, in addition to correlating the sociodemographic variables with the mean score (scale from 0 to 100).

Finally, to assess health perception, the correlation between the clinical variables and two specific questions of the WHOQOL-HIV Bref instrument was used: "How is your health?", With answers ranging from "very bad" to "very good", and "Do you consider yourself sick today?", with "yes" and "no" as possible answers.

The project was submitted and approved by the Research Ethics Committee (Comitê de Ética em Pesquisa, CEP) involving human beings of the UFPE, presenting CAAE No.: 76367817.0.0000.5208. All the ethical aspects of research involving human beings were respected, as well as the patients in their autonomy and dignity, according to Resolution 466/12 of the National Health Council (Conselho Nacional de Saúde, CNS).

\section{Results}

On average, 1,185 patients received medication for the treatment of HIV/AIDS infection on a monthly basis at the hospital where the research was conducted, from November 2017 to April 2018. Through the prescriptions received in the outpatient pharmacy, about 40 individuals being treated for TB and using anti-retroviral therapy (ART) were identified. Applying the inclusion criteria used in the present study, interviews were carried out with $26 \mathrm{HIV} / \mathrm{TB}$ 
co-infected patients, which corresponds to $65 \%$ of the patients with HIV/TB co-infection treated during the study period.

Table 1 presents the sample's sociodemographic description. The profile of the participants was made up mostly of men, heterosexual, single, of productive age (29-38 years old), without employment, and with unfavorable socioeconomic conditions. The vast majority of the patients lived in Recife or in cities in the Metropolitan Region of Recife.

Table 1. Sociodemographic characterization of HIV/TB co-infected patients with quality of life values below and above the mean (69.6) in the 0-100 score range, interviewed from November 2017 to April 2018 (N=26).

\begin{tabular}{|c|c|c|c|}
\hline Variables & n (\%) & Quality of life < 69.6 n (\%) & Quality of life $>69.6 n(\%)$ \\
\hline \multicolumn{4}{|l|}{ Gender } \\
\hline Male & $20(76.9)$ & $10(38.5)$ & $10(38.5)$ \\
\hline Female & $6(23.1)$ & $4(15.4)$ & $2(7.7)$ \\
\hline \multicolumn{4}{|l|}{ Age (years old) } \\
\hline 18 to 28 & $5(19.2)$ & $3(11.5)$ & $2(7.7)$ \\
\hline 29 to 38 & $12(46.1)$ & $9(34.6)$ & $3(11.5)$ \\
\hline 39 to 48 & $5(19.2)$ & $2(7.7)$ & $3(11.5)$ \\
\hline 49 to 59 & $2(7.7)$ & - & $2(7.7)$ \\
\hline$\geq 60$ & $2(7.7)$ & - & $2(7.7)$ \\
\hline \multicolumn{4}{|l|}{ Marital status } \\
\hline Single & $19(73.1)$ & $11(42.3)$ & $8(30.8)$ \\
\hline Married & $5(19.2)$ & $2(7.7)$ & $3(11.5)$ \\
\hline Widow/Widower & $2(7.7)$ & $1(3.8)$ & $1(3.8)$ \\
\hline \multicolumn{4}{|l|}{ Schooling } \\
\hline Illiterate & $3(11.5)$ & $1(3.8)$ & $2(7.7)$ \\
\hline Elementary School & $9(34.6)$ & $6(23.1)$ & $3(11.5)$ \\
\hline High School & $11(42.3)$ & $6(23.1)$ & $5(19.2)$ \\
\hline Higher Education & $3(11.5)$ & $1(3.8)$ & $2(7.7)$ \\
\hline \multicolumn{4}{|l|}{ Residence } \\
\hline Recife & $17(65.4)$ & $8(30.8)$ & $9(34.6)$ \\
\hline Other cities of the MRR & $8(30.8)$ & $5(19.2)$ & $3(11.5)$ \\
\hline Other state & $1(3.8)$ & $1(3.8)$ & - \\
\hline \multicolumn{4}{|l|}{ Employment contract } \\
\hline No current contract & $23(88.5)$ & $13(50.0)$ & $10(38.5)$ \\
\hline Retired & $1(3.8)$ & - & $1(3.8)$ \\
\hline Student & $1(3.8)$ & $1(3.8)$ & - \\
\hline Unknown & $1(3.8)$ & - & $1(3.8)$ \\
\hline \multicolumn{4}{|c|}{ Family income (minimum wages) ${ }^{1}$} \\
\hline Less than 1 & $12(46.1)$ & $8(30.8)$ & $4(15.4)$ \\
\hline 1 to 2 & $11(42.3)$ & $5(19.2)$ & $6(23.1)$ \\
\hline 3 to 5 & $2(7.7)$ & $1(3.8)$ & $1(3.8)$ \\
\hline+5 & $1(3.8)$ & - & $1(3.8)$ \\
\hline
\end{tabular}

${ }^{1}$ The minimum wage in the study period varied from $R \$ 937$ (2017) to $R \$ 954$ (2018). N- Number of patients (total of N=26); MRR- Metropolitan Region of Recife.

Despite being at the height of their productive age and educational attainment, the morbidity caused by HIV/TB coinfection prevented professional activity in $100 \%$ of the cases at some point during the treatment period.

The clinical variables evaluated in the study, as well as the time of use and the detailed schemes of ART and TB treatment, are described in Table 2. All the patients were using tuberculostatic drugs, and $92.3 \%$ of them were already on ART when interviewed. However, the alternative regimens used in ART did not show drug interaction with the tuberculostatic drugs used.

Two study participants were being treated for multidrug-resistant TB (MDR-TB), using the following drugs: capreomycin, levofloxacin, ethambutol, terizidone, and pyrazinamide. Regarding other drugs used by the patients to treat opportunistic infections or other comorbidities, antibiotics and antifungals were the predominant ones.
In the assessment of quality of life (Table 3 ), the domains with the best mean values were spirituality $(15.5 \pm 3.8)$ and psychological $(15.3 \pm$ 2.2 ), while the worst mean was obtained in the level of independence $(11.1 \pm 2.6)$ domain. The overall quality of life, with a score from zero (worst quality of life) to one hundred (best quality of life), obtained results ranging from 57.4 to 92.9 , with a mean of $69.6 \pm 9.1$.

Among the patients with a quality of life below the mean, with regard to the score of 0-100, most were aged 29-38 years old, single, without employment, and with a family income below 1 minimum wage (Table 1 ).

As for the reliability of the questionnaire (Table 3), Cronbach's Alpha coefficient values greater than 0.70 were obtained in 5 of the 6 domains. The same was also calculated for the total questionnaire, obtaining a value of 0.9 , which demonstrates good internal consistency of the instrument. 
Table 2. Clinical characterization and health perception of the patients with HIV/TB co-infection interviewed from November 2017 to April $2018(\mathrm{~N}=26)$

\begin{tabular}{|c|c|c|c|c|c|}
\hline \multirow{2}{*}{ Data } & \multirow{2}{*}{$\begin{array}{l}\text { All the patients } \\
n(\%)\end{array}$} & \multicolumn{2}{|c|}{$\begin{array}{l}\text { Health perception } \\
n(\%)\end{array}$} & \multicolumn{2}{|c|}{$\begin{array}{l}\text { Consider themselves ill } \\
n(\%)\end{array}$} \\
\hline & & Good or Very good & Indifferent or Bad & No & Yes \\
\hline \multicolumn{6}{|l|}{ ART treatment time (years) } \\
\hline 0 to 2 & $17(65.4)$ & $12(46.1)$ & $5(19.2)$ & $11(42.3)$ & $6(23.1)$ \\
\hline 3 to 6 & $4(15.4)$ & 3 (11.5) & $1(3.8)$ & $4(15.4)$ & - \\
\hline 7 to 10 & $3(11.5)$ & $3(11.5)$ & - & $2(7.7)$ & $1(3.8)$ \\
\hline$>10$ & $2(7.7)$ & $1(3.8)$ & $1(3.8)$ & $1(3.8)$ & $1(3.8)$ \\
\hline \multicolumn{6}{|l|}{ TB treatment time (months) } \\
\hline 1 to 3 & $11(42.3)$ & $8(30.8)$ & $3(11.5)$ & $8(30.8)$ & $3(11.5)$ \\
\hline 4 to 6 & $9(34.6)$ & $7(26.9)$ & $2(7.7)$ & $6(23.1)$ & $3(11.5)$ \\
\hline+6 & $6(23.1)$ & $4(15.4)$ & $2(7.7)$ & $4(15.4)$ & $2(7.7)$ \\
\hline \multicolumn{6}{|l|}{ Way of infection (HIV) } \\
\hline Sexual & $15(57.7)$ & $9(34.6)$ & $6(23.1)$ & $8(30.8)$ & 7 (26.9) \\
\hline Work accident & $1(3.8)$ & - & $1(3.8)$ & $1(3.8)$ & - \\
\hline Blood derivatives & $2(7.7)$ & $2(7.7)$ & - & $2(7.7)$ & - \\
\hline Vertical transmission & $1(3.8)$ & $1(3.8)$ & - & $1(3.8)$ & - \\
\hline $\begin{array}{l}\text { Others (Does not know/Did not } \\
\text { answer) }\end{array}$ & 7 (26.9) & 7 (26.9) & - & $6(23.1)$ & $1(3.8)$ \\
\hline \multicolumn{6}{|l|}{ CD4 ${ }^{1}\left(\right.$ cells $\left./ \mathrm{mm}^{3}\right)$} \\
\hline$<50$ & $4(15.4)$ & $4(15.4)$ & - & $4(15.4)$ & - \\
\hline 51 to 250 & $13(50)$ & $9(34.6)$ & $4(15.4)$ & $8(30.8)$ & $5(19.2)$ \\
\hline 251 to 500 & $5(19.2)$ & $5(19.2)$ & - & $4(15.4)$ & $1(3.8)$ \\
\hline$>500$ & $3(11.5)$ & $1(3.8)$ & $2(7.7)$ & $1(3.8)$ & $2(7.7)$ \\
\hline Unknown & $1(3.8)$ & - & $1(3.8)$ & $1(3.8)$ & - \\
\hline \multicolumn{6}{|l|}{ Viral load* (viral RNA/mL) } \\
\hline$<50$ copies & $13(50.0)$ & $10(38.5)$ & $3(11.5)$ & $10(38.5)$ & $3(11.5)$ \\
\hline 50 to 1,000 copies & $3(11.5)$ & $1(3.8)$ & $2(7.7)$ & $2(7.7)$ & $1(3.8)$ \\
\hline$>1,000$ copies & $9(34.6)$ & $8(30.8)$ & $1(3.8)$ & $5(19.2)$ & $4(15.4)$ \\
\hline Unknown & $1(3.8)$ & - & $1(3.8)$ & $1(3.8)$ & - \\
\hline Comorbidities $^{2}$ & $3(11.5)$ & $3(11.5)$ & - & $2(7.7)$ & $1(3.8)$ \\
\hline \multicolumn{6}{|l|}{ Therapeutic regimen (ART) } \\
\hline$R A L+(T D F+3 T C)$ & $11(42.3)$ & $9(34.6)$ & $2(7.7)$ & $7(26.9)$ & $4(15.4)$ \\
\hline$E F V+(T D F+3 T C)$ & $10(38.5)$ & $6(23.1)$ & $4(15.4)$ & $7(26.9)$ & $3(11.5)$ \\
\hline $\mathrm{DTV}+(\mathrm{TDF}+3 \mathrm{TC})$ & $2(7.7)$ & $2(7.7)$ & - & $1(3.8)$ & $1(3.8)$ \\
\hline Others & $3(11.5)$ & $2(7.7)$ & $1(3.8)$ & $3(11.5)$ & - \\
\hline \multicolumn{6}{|l|}{ Therapeutic regimen (TB) } \\
\hline RHZE (intensive phase) & $7(26.9)$ & $5(19.2)$ & $2(7.7)$ & $5(19.2)$ & $2(7.7)$ \\
\hline RH (maintenance phase) & $14(53.8)$ & $11(42.3)$ & $3(11.5)$ & $9(34.6)$ & $5(19.2)$ \\
\hline Multi-resistance & $2(7.7)$ & $1(3.8)$ & $1(3.8)$ & $1(3.8)$ & $1(3.8)$ \\
\hline Others & $3(11.5)$ & $2(7.7)$ & $1(3.8)$ & $3(11.5)$ & - \\
\hline
\end{tabular}

${ }^{1}$ Results of exams performed in the period closest to the interview (up to 6 months). ${ }^{2}$ Dichotomous variable, presented in only one category. Abbreviations: per cubic millimeter (/mm ${ }^{3}$ ), per milliliter (/mL), raltegravir (RAL): tenofovir (TDF): lamivudine (3TC): efavirenz (EFV); dolutegravir (DTV); rifampicin + isoniazid + pyrazinamide + ethambutol (RHZE): rifampicin + isoniazid (RH).

Regarding health perception, $73.1 \%$ considered their health "good" or "very good" (Tables 2 and 3), where most of them were in the first two years of using ART and in the maintenance phase of the tuberculosis treatment. It was also observed that, of the 8 patients with TCD4 ${ }^{+}$lymphocyte counts below 350 cells $/ \mathrm{mm}^{3}$ and viral loads above 1,000 copies $/ \mathrm{mL}, 7$ had a positive perception of their health.

The presence of three comorbidities in different patients has been reported: hypertension, hypercholesterolemia, and plasmablastic lymphoma. Despite their condition, they all considered their health to be "good".

When asked "if there is something wrong with yourself", $46.1 \%$ reported that there was nothing wrong. Tiredness or weakness was described by $19.2 \%$ of the patients, in addition to leg pain, another symptom reported by $11.5 \%$ of the interviewees.

The other reports included the following: arrhythmia, chest pain, stomach pain, dizziness, depression and psychological shock, dissatisfaction with low body weight, fear of infecting the partner, lack of respect for HIV status, and discouragement due to the end of the relationship.

Among the individual facets, the worse mean values showed that most of the patients interviewed recognized the need for medical treatment to lead their daily lives and had little money to meet their needs. However, the higher scores showed that most of the respondents believed that their lives had meaning and were able to accept their physical appearance. 
Table 3. Quality of life assessment and WHOQOL-HIV Bref domain score of the HIV/TB co-infected patients interviewed from November 2017 to April 2018 ( $N=26)$.

\begin{tabular}{lll}
\hline Variables & N & (\%) \\
\hline Health perception & 4 & 15.4 \\
Very good & 15 & 57.7 \\
Good & 6 & 23.1 \\
Neither bad or good & 1 & 3.8 \\
Poor & & \\
Consider themselves ill & 18 & 69.2 \\
No & 8 & 30.8 \\
Yes & & \\
General assessment of quality of life & 2 & 7.7 \\
Very good & 10 & 38.5 \\
Good & 12 & 46.1 \\
Neither good or bad & 2 & 7.7 \\
Poor & & \\
Satisfaction with life & 3 & 11.5 \\
Very satisfied & 19 & 73.1 \\
Satisfied & 3 & 11.5 \\
Neither dissatisfied or satisfied & 1 & 3.8 \\
Dissatisfied & & Cronbach's alpha \\
Quality of life domain & Mean \pm SD & coefficient \\
Physical & $14.2 \pm 2.7$ & 0.71 \\
Psychological & $15.3 \pm 2.2$ & 0.73 \\
Level of independence & $11.1 \pm 2.6$ & 0.71 \\
Social relationships & $14.2 \pm 2.9$ & 0.69 \\
Environment & $13.4 \pm 2.2$ & 0.74 \\
Spirituality & $15.5 \pm 3.8$ & 0.76 \\
\hline SD:Stard Den & & \\
\hline
\end{tabular}

${ }^{1} \mathrm{SD}$ : Standard Deviation

\section{Discussion}

The profile characterized by men of working age, low schooling and low income was described by several authors, confirming this population as the most vulnerable and prevalent for co-infection by $M$. tuberculosis and HIV ${ }^{6,7,10}$.

As for the age group, the tendency is for the mean age of the patients with HIV/AIDS and TB to increase ${ }^{11}$. This increase may mean an increase in the life expectancy of individuals, as several studies claim that ART users with viral suppression and increased TCD4+ lymphocyte count for $\geq 500$ cells $/ \mathrm{mL}$ can reach life expectancy levels similar to the general population ${ }^{12,13}$.

The low schooling level associated with low income may influence

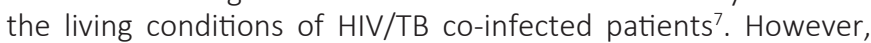
despite the fact that a large part of the interviewees in the present study reached high school and graduation, the absence of an employment contract was a reason for great dissatisfaction for most of them.

Another study also showed that more than half of the participants were unemployed at the time of the interview. The main cause of the absence of an employment contract was related to the health conditions and to the diagnosis of the HIV/AIDS infection ${ }^{14}$.

The fact that the patients live in Recife or in nearby cities should be a positive point for adherence. However, in some cases, the proximity to the health service did not prevent treatment abandonment.

In the assessment of the clinical aspects, it was observed that most of the patients had a diagnosis of both diseases in a near period. This fact shows that the active search for TB was being carried out in HIV-infected patients, as well as the HIV test in patients with TB. Early diagnosis is an important ally in the treatment of these diseases ${ }^{11}$.

Regarding HIV transmission, sexual transmission was observed in $57.7 \%$ of the interviewees, corroborating with epidemiological data found in Brazil and in the world ${ }^{4,14}$. However, another $26.9 \%$ did not want to give an opinion or reported not knowing how they had become infected.

The extent of treatment with tuberculostatic agents for some patients was identified in the present study. When the initial clinical evolution is not satisfactory, TB treatment can be prolonged in the maintenance phase, which often occurs in patients co-infected with HIV and in cases of mono-resistance to rifampicin or isoniazid ${ }^{15}$.

More than half of the interviewees showed an advanced stage of immune compromise, with a TCD4 ${ }^{+}$lymphocyte count below 200 cells $/ \mathrm{mm}^{3}$ of blood, corroborating with other studies ${ }^{6,11}$.

The undetectable viral load demonstrates a good performance of ART and good adherence to the treatment in these patients. However, when elevated, it indicates a warning sign for therapeutic failure or difficulties in adherence.

Among the few reported comorbidities, hypercholesterolemia and hypertension are relatively common in the general population. However, plasmablastic lymphoma is a rare type of neoplasia, classified as non-Hodking lymphoma, which mainly affects HIVinfected patients ${ }^{16}$.

Smoking, alcoholism, and the use of illicit drugs were reported by some patients, which is a worrying indication for the outcome of these cases. According to some authors, the highest nonadherence rates in relation to the treatment were in younger patients, aged 20-39 years old and who used alcohol ${ }^{17}$.

As for TB treatment, alternative therapies can be used in cases of adverse reaction to the basic regimen containing rifampicin, or due to interactions with the drugs used in ART. However, patients with MDR-TB should be treated with a greater association of drugs. The use of alternative treatments or resistance to multiple drugs in TB may also indicate non-adherence to the basic treatments².

With regard to $A R T$, the association between raltegravir, tenofovir and lamivudine (RAL/TDF/3TC) is the recommended option for cases of contraindication to the use of efavirenz. The schemes containing efavirenz have greater dose comfort and higher longterm adherence rates to the treatment ${ }^{18}$.

The incidence of opportunistic infections increases the use of medications, such as antibiotics and antifungals, present in the prescriptions of the patients participating in the study.

A number of studies comparing individuals infected only with HIV to others with HIV/TB co-infection demonstrated that the presence of co-infection interfered with quality of life, which was lower in co-infected patients ${ }^{4,8}$. 
In the present study, more than two thirds of the interviewees rated their health as "good" or "very good" and said they were satisfied with their lives. This positive health perception, despite the HIV condition associated with a disease such as TB, can mean advances and efficacy in therapeutic strategies, suppressing the clinical signs and symptoms that would cause a worse perception about one's own health.

However, the number of patients with severe immunodeficiency and high viral titers who demonstrated a positive perception of their health is a warning sign, as they may neglect treatments and the risk they are still subjected to when they have HIV/TB co-infection. Therefore, it is essential that these patients are encouraged to never abandon their treatments.

The scores obtained in the domains reveal the relationship between them and the quality of life of the individuals. The low score of the level of independence demonstrated the limitations of the patients, who depended on the medical treatment to be able to continue their lives and perform basic activities like walking and working.

The environment domain had the second worse score, highlighted mainly by the unfavorable economic conditions, which affect most of the individual questions present in this domain. Individuals with higher schooling levels and better socioeconomic conditions generally have higher scores ${ }^{19}$

Regarding the psychological domain, even with high scores, some patients described negative symptoms, among them: depression, dissatisfaction with low body weight, fear of infecting their partner, and discouragement due to the end of the relationship.

The lowest mean values for the physical domain are directly related to worse clinical and socioeconomic conditions. However, it is known that anti-retroviral drugs provide more energy, improve self-esteem and the ability to walk, positively influencing the physical, psychological, and independence levels $s^{6,21}$.

In the social relations domain, some patients reported social isolation and dissatisfaction with the lack of respect they were victims of due to their HIV status. Others said that few people were aware of their health conditions in an attempt to escape social judgment. The cause of social isolation and difficulty in relationships can be explained by fear of suffering prejudice, also reported in other studies 2,21 .

Spirituality has been shown to be the domain with the highest score in several studies ${ }^{6,19}$. However, many patients reported fear of the future and concern about death. Spiritual well-being can also help people with HIV/TB to decrease problems in the progression of the disease and, thus, has a direct contribution to the quality of life of these individuals ${ }^{22}$.

The importance of carrying out the treatment correctly was evidenced in another study ${ }^{23}$, in which a considerably positive change in the quality of life of patients with HIV/TB co-infection was seen after 6 months of treatment.

The monitoring of patients with HIV and TB must be carried out differently, often for a period of more than 6 months. The cases of treatment abandonment and the change of the service location can significantly interfere in the outcome of these patients ${ }^{11}$.

Regarding the limitations of the study, the small sample size is mentioned, which can interfere with the analysis, but does not invalidate the results obtained. Many patients did not show up to receive the medications at the hospital's pharmacy because they were very weak. Others still did not adhere correctly to the treatment, spending months without attending the appointments and receiving the medications. In addition to the cases of the patients who died while hospitalized, or who were transferred to other hospital units.

Therefore, the health team must be involved in order to provide greater adherence to the treatment, with the role of the pharmacist in the pharmacotherapeutic monitoring and guidance of patients regarding the schemes used being of great importance. In addition to ensuring the effectiveness of the treatment, the evaluation of pharmacotherapy by the pharmacist guarantees safety of use and reduces problems related to medications ${ }^{25}$.

\section{Conclusion}

The changes in the quality of life domains are due to the burden of weakness caused by the two infections, mainly in cases where there is no adequate adherence to the treatment. The decrease in work capacity, the extreme dependence on the treatment for the continuation of life, and the socioeconomic conditions were the aspects that most influenced the quality of life of the studied population. Despite this, most of the patients preserved self-esteem, personal satisfaction, and optimism regarding the disease condition. Greater interaction by the multi-professional team associated with the integration of HIV and TB services could bring many benefits to the clinical outcome of this population, contributing to improving the quality of life of these individuals.

\section{Funding sources}

This research did not receive funding from any institution or company.

\section{Collaborators}

ADS: conception, design, data collection, data analysis and interpretation, writing of the article. RMFS: conception, design, guidance in writing, relevant critical review for the content, and final approval of the version to be published. MJTI: guidance in writing, review of the collected data, critical review of the manuscript. JARF: conception, critical review of the manuscript. AMBA: data collection, critical review of the manuscript. TCSA: review of the collected data and critical review of the manuscript. The authors were responsible for all the aspects of the work in ensuring the accuracy and integrity of any part of the paper.

\section{Acknowledgments}

We are grateful to the hospital where the study took place for the institutional support, and to all the employees of the Outpatient Pharmacy for their contribution during the data collection period.

\section{Conflict of interest statement}

The authors declare that there are no conflicts of interest regarding this article. 


\section{References}

1. World Health Organization. HIV-Associated Tuberculosis. Available in: https://www.who.int/tb/areas-of-work/tb-hiv/ tbhiv_factsheet.pdf. Accessed on: April 28, 2020.

2. Neves LAS, Reis RK, Gir E. Compliance with the treatment by patients with the co-infection HIV/tuberculosis: integrative literature review. Rev Esc Enferm USP. 2010; 44(4):1129-1134.

3. World Health Organization. Global tuberculosis report 2019. Available in: https://apps.who.int/iris/bitstream/ handle/10665/329368/9789241565714-eng.pdf?ua=1 Accessed on: April 28, 2020.

4. Deribew A, Tesfaye M, Hailmichael $Y$, et al . Tuberculosis and HIV co-infection: its impact on quality of life. Health Qual Life Out. 2009; 7(105):1-7.

5. Louw J, Peltzer K, Naidoo P, et al. Quality of life among tuberculosis (TB), TB retreatment and/or TB-HIV co-infected primary public health care patients in three districts in South Africa. Health Qual Life Out. 2012; 10 (77): 1-8.

6. Neves LAS. Qualidade de vida de indivíduos com a coinfecção HIV/Tuberculose no município de Ribeirão Preto- SP [Tese de Doutorado]. Escola de Enfermagem de Ribeirão, Universidade de São Paulo, Ribeirão Preto, 2010.

7. Lemos LA, Feijão AR, Gir E, et al. Aspectos da qualidade de vida de pacientes com coinfecção HIV/tuberculose. Acta Paul Enferm. 2012; 25 (Esp.1):41-47.

8. Feijão AR, Gir E, Galvão MTG. Quality of Life of Patients with HIV/Tuberculosis Coinfection Experiencing Nursing Consultation. Int Arch Med. 2016; 9(56):1-8.

9. World Health Organization. WHOQOL-HIV Instrument Users Manual. Available in: https://www.who.int/mental_health/ media/en/613.pdf. Accessed on: April 28, 2020.

10. Prado TN, Miranda AE, Souza FM, et al. Factors associated with tuberculosis by HIV status in the Brazilian national surveillance system: a cross sectional study. BMC Infect Dis 2014; 14(415):1-8

11. Cheade MFM, Ivo ML, Siqueira PHGS, et al. Caracterização da tuberculose em portadores de HIV/AIDS em um serviço de referência de Mato Grosso do Sul. Rev Soc Bras Med Trop. 2009; 42(2):119-125.

12. May MT, Gompels M, Delpech V, et al. Impact on life expectancy of HIV-1 positive individuals of CD4R cell count and viral load response to antiretroviral therapy. AIDS. 2014; 28 (8): 1193-1202.

13. Lewden $\mathrm{C}$, Bouteloup $\mathrm{V}$, Wit $\mathrm{S}$, et al. All-cause mortality in treated HIVinfected adults with CD4 $\geq 500 / \mathrm{mm} 3$ compared with the general population: evidence from a large European observational cohort collaboration. Int J Epidemiol. 2012;41(2):433-445.

14. Neto JFR, Lima LS, Rocha LF, et al. Perfil de adultos infectados pelo vírus da imunodeficiência humana (HIV) em ambulatório de referência em doenças sexualmente transmissíveis no norte de Minas Gerais. Rev Med Minas Gerais. 2010; 20(1):22-29.
15. Brasil. Ministério da Saúde. Manual de recomendações para o controle da tuberculose no Brasil. Available in: http://bvsms. saude.gov.br/bvs/publicacoes/manual_recomendacoes controle_tuberculose_brasil.pdf. Accessed on: April 28, 2020.

16. Salas AA, Juarez PC, Calvo PJS. Coexistencia de linfoma plasmablástico, sarcoma de Kaposi y enfermedad de Castleman en un paciente con infección por virus de inmunodeficiencia humana. Rev Chil Infectol. 2011; 28(1):7680.

17. Prado TN, Rajan JV, Miranda AE, et al. Clinical and epidemiological characteristics associated with unfavorable tuberculosis treatment outcomes in TB-HIV co-infected patients in Brazil: a hierarchical polytomous analysis. Braz J Infect Dis. 2017 Mar-Abr; 21(2):162-170.

18. Rockstroh JK, DeJesus E, Lennox JL, et al. Durable efficacy and safety of raltegravir versus efavirenz when combined with tenofovir/emtricitabine in treatment-naive HIV-1-infected patients: final 5-year results from STARTMRK. I Acquir Immune Defic Syndr. 2013 May; 63(1):77-85.

19. Reis RK. Qualidade de vida de portadores do HIV/aids: influência dos fatores demográficos, clínicos e psicossociais [Tese de Doutorado]. Universidade de São Paulo, Ribeirão Preto. 2008.

20. Campos LN, César CC, Guimarães MDC. Quality of life among HIV-infected patients in Brazil after initiation of treatment. Clinics. 2009; 64(9):867-875.

21. Neves LAS, Castrighini CC, Reis RK, et al. Suporte social e qualidade de vida de indivíduos com coinfecção tuberculose/ HIV. Enferm Glob. 2018 Abr; 50: 11-20

22. Calvetti PÜ, Muller MC, Nunes MLT. Qualidade de vida e bemestar espiritual em pessoas vivendo com HIV/aids. Psicol Estud. 2008 Jul- Set; 13(3):523-530.

23. Deribew A, Deribe $K$, Reda AA, et al. Change in quality of life: a follow up study among patients with HIV infection with and without TB in Ethiopia. BMC Public Health. 2013; 13(408):1-6.

24. Moriel P, Carnevale RC, Costa CGR, et al. Efeitos das intervenções farmacêuticas em pacientes HIV positivos: Influência nos problemas farmacoterapêuticos, parâmetros clínicos e economia. R. Bras. Farm. Hosp. Serv. Saúde. 2011 Set-Dez; 2(3):5-10. 